\title{
Temperature Conditions for Determination of Beekeeping Regions in the Light of Climate Change. Case study: Fars Province
}

\author{
Aliakbar SALEHIZADEH ${ }^{1}$, Morteza KHODAGHOLI ${ }^{2}$, Amir GANDOMKAR $^{3 *}$ \\ ${ }^{1}$ Department of Geography, Najafabad Branch, Islamic Azad University, Najafabad, Iran \\ ${ }^{2}$ Rangeland Research Division, Rangelands and Forests of Institute Research, Agricultural Research \\ Extension Education Organization (AREEO), Tehran, Iran \\ ${ }^{3}$ Department of Geography, Najafabad Branch, Islamic Azad University, Najafabad, Iran
}

\begin{abstract}
The importance of the honey bee lays in its huge role in pollination and, as a result, maintaining the flora of the environment and also increasing agricultural production. Temperature is the most important element of the atmosphere affecting beekeeping. Results of stationary conclusions are generalized to the area of Fars province by using geographical information system (GIS) according to direct relationship between elevation changes and temperature variations. A beekeeping capability map was then drawn for the Fars province by months of the year. The results showed that heat conditions in four months of the year, from December to March, are not suitable in most of the northern and eastern parts of the province. The southern regions with an altitude of less than $\mathbf{1 1 0 0}$ meters above sea level are considered as a suitable place for deployment, wintering and beginning of bee colony activities. The most optimal months of the year for honey bee activities are May and October. For fixed beekeeping, the central strip of the province with an average height of 1500 meters above sea level is the most suitable places.
\end{abstract}

Keywords - Fars; geographical information system; honey bee; pollination; temperature.

\section{INTRODUCTION}

One of the most valuable creatures in nature is the honey bee [1]. In addition to pollination of plants, that in fact the greatest purpose for environment and human being, the honey bee also has an important role in the beekeeping industry and many other industries like pharmaceutical, cosmetic, candle productions, textile, paper and leather production, etc. By production of products such as honey, wax, propolis, Royal gel and poison, the honey bee plays a role in the economy of the country by creating jobs in the sectors related to production of beekeeping tools, conveyor workshops, honey and beeswax packing factories [2]. In other words, beekeeping has many advantages that help the people of the area to improve their economic and nutritional requirements [3]. In the United States, more than 130 species, and worldwide, more than 400 species of agricultural products are pollinated by honey bees [4]. The lack of pollination by honey bees can damage up to 75 percent of the agricultural yield [5]. Beekeeping is one of the agricultural sector's elements most affected by weather conditions. By identifying and determining the climatic potential of each region, it is possible to determine the biological conditions of any species

\footnotetext{
* Corresponding author.

E-mail address: aagandomkar@yahoo.com 
of plant and animal based on the conditions in terms of time and place [6]. Beekeeping has a close relationship with climatic conditions. Heat conditions of every region determine the activity of the honey bee by flower production. There is a direct relationship between climatic parameters, specially temperature and production of honey bee colonies [7]. The thermal conditions of the environment determine the activity of the bee and its production rate [8]. The honey bee, known as Apis Mellifera which is one of the arthropods and insect species, is a bee species that produces honey. The bee does this by collecting the nectar of the flowers in a hive [9]. At the moment, honey bees are scattered all over the world except cold and freezing regions of the north and south poles. In addition to naturally being in their habitat, the honey bee is also raised in large numbers, either through traditional or modern methods, and plays an indispensable role in plant proliferation and survival of animals. Considering that the honey bee is cold-blooded and has a strong dependence on environment conditions, any change in climate and its surroundings will have a direct impact on its life [10]. Climate change has been recognized as a major challenge to human beings and natural ecosystems [11].

The native breed of the Iranian bee is from the Apis Mellifera $L$ which is also mentioned as the Apis Millifera Iranica, Apis Millifera Meda and Apis Millifera Persica. This species has lived in the territory of Iran for thousands of years and has been adapted to climate conditions, pests and diseases in different parts of the country; indeed, it has some unique features introducing it as one of world's famous species [9]. As described in studies, the first three rings of the Iranian bee abdomen are black and the rest of the body is grayish yellow. Their growth is good and they reach their peak by June. In cold regions, winter temperatures are well tolerated. Production and use of their beeswax is high and its unfavourable features can be highlighted by the desire to plunder and produce eggs [2].

Blumberga et al. (2019) believes that in recent years, research in environmental and climate issues becomes more and more broad and obtains new dimensions in connection with socioeconomic science [12]. Reference [13] describes climate and pollinators change in a study and describes how climate condition change is considered as the most severe potential threat in pollinator biodiversity. Reference [14] evaluated climate potential of honey bee colonies breeding at the level of selected stations in Ilam province for agricultural development. Flowering condition, colony immigration forecast, bio accumulation, heat potential and thermal regime have been analysed. Finally, all areas of the province are discussed separately in terms of climate potential of honey bee colony breeding. Reference [15] carried out a climatic study of phylogenetics based on studies for production of bees in Ilam. By using the methods of plant phenological study and determining the flowering date and its way of predicting as a model, a new method has been prepared for determining the annual calendar of beekeeping. Reference [16] states that climate change is responsible for the destruction of the bee population. Furthermore, this reference outlines the problem of global warming and its negative effects on the honey bee and a wide range of these important pollinator insects. Constraints that have arisen with increasing temperatures has caused the movement of various bee species residence $300 \mathrm{~km}$ to the North in many parts of southern North America and Europe. Reference [17] in examination of different honey bee activities in order to be pollinated according to temperature conditions in the city of Riyadh in Saudi Arabia determined that there is a correlation between honey bee activities and temperature in different seasons. Reference [18] determined in the study of collected nectar and pollen by honey bee colonies in the botanical garden of Egypt that the highest collected pollen has been in the spring and there is a high and positive correlation between the average of minimum and maximum temperatures and the amount of pollen. Reference [19] in a valuable study, investigated the optimal location searching for honey bee breeding under severe environmental conditions by using a geographical information system (GIS) for Saudi Arabia. For this purpose, 
digital layers of temperature, relative humidity, vegetation cover and water resources were used. According to their results, the temperature layer has the highest weight for identifying the optimum location of honey bee breeding. Reference [20] conducted research on the relationship between climate and phenological stages advancement of bees and pollen bees. In this research, an analysis of climate change is done associated with phenology of wild honey bees and important pollinating insects. Reference [6] studying the bioclimatic aspects of beekeeping in Iran, case study of Isfahan Province has shown that spatial and temporal optimization through the thresholds for honey bee grazing plays an effective role in beekeeping calendar and beekeeping cycle following the climatic and elevation conditions of each region. Reference [7] by studying climatic elements' effect on honey bee breeding in Salmas town has determined that honey bee activities have a reverse relationship with rain and a direct relationship with temperature effects in special thresholds. Reference [21] has examined geographical and climatic conditions effect on separation of populations of small honey bees and concluded that the honey bees in cold and high areas are bigger than those in other areas. Reference [22] based on correlation methods and regression analyses have evaluated the effect of climate elements on performance of native honey bee hive in Ahar town. Their results showed that the minimum temperature in spring and days with more than $35^{\circ} \mathrm{C}$ temperature are favourable for honey bee performance. Reference [23] conducted regular field visits and sampling for preparing beekeeping calendar of the Nazluchay and Rozechay watershed area in western Azerbaijan after preparing topographic maps and determining rangeland nectar producer species and then beekeeping calendar.

In the territory of Iran, climate variation has provided a suitable platform for activities in various fields of agriculture, including beekeeping which helps to understand the potential abilities and the manner in which environmental factors may affect beekeeping. Success in honey bee breeding depends on having enough knowledge and information about hive organization, growth and beekeeper behaviour in relation to the environment in order to apply correct management. The Fars province has the appropriate climate conditions for potential to develop the beekeeping industry. These conditions have led to immigration of 50000 to 60000 colonies from other provinces to this province to take advantage of the weather conditions in this area at the beginning of autumn and in the winter, which has also increased honey production [24]. The average amount of honey production in the province is about 4500 tons and this industry led to employment of 5900 young people. The export of 10 percent of Fars honey produces an annual income of 2.5 million US dollars for the province [25]. In this regard, it is very necessary and indisputable to carry out research on temperature testing and presentation of regional maps of beekeeping in the country. Identification of suitable regions for beekeeping by regional maps in all months of the year will enable beekeepers to determine the best region to settle the bee colonies and the most proper time and place for migration of hives. Thus, regional actions are often consistent with the national actions and it is important to evaluate the climate perspective for both national and regional decisions [26].

\section{Methods And Procedures}

The Fars province with an area of $12208 \mathrm{~km}^{2}$ is located between $27^{\circ} 3^{\prime}$ and $31^{\circ} 40^{\prime}$ longitude is $50^{\circ} 36^{\prime}$ and $55^{\circ} 35^{\prime}$ east longitude from the Greenwich meridian. This province is located in the south of the Iranian plateau and is bordered by Isfahan from the north, Hormozgan from the south east, Kerman and Yazd provinces from the east, Kohgiluyeh and Boyerahmad from the northwest and Bushehr province from the west. According to the last divisions of the country in April 2011, the Fars province has 29 cities: Abadeh, Arsanjan, Estahban, Eghlid, Bovanat, Pasargad, Jahrom, Kherame, Khorambid, Khonj, Darab, Rostam, Zarindasht, Sepidan, Sarvestan, Shiraz, 
Farashband, Fasa, Firouzabad, Ghir o Karzin, Kazeroun, Kavar, Gerash, Larestan, Lamerd, Marvdasht, Mamasani, Mohr and Neyriz. Fars province is affected by its topographical features and due to its diverse climate types and natural geographic structures, it has unique spaces. The area contains four climatic zones: cold and dry region in the northern are of the Fars Province, temperate and humid regions in the central area, warm and semi-humid areas in the west, and dry and warm areas in the south [27].

Honey bees perform a special service by pollinating several plant species. The performance of honey bees, however, depends on the over-all health of the colony and their activities which directly depend on the availability of the bee flora in the region [28]. Due to the wide scope of honey bee activities, both in terms of flight radius and vegetation diversity, the research on honey bee activity was not limited only to activities related to the flowering of certain native plant species. Data on minimum and maximum daily and monthly temperatures from Fars province meteorological stations were used in this research. In the study of climatic homogeneity conditions in Fars Province with heat demand of honey bee, data from the meteorological station of the province has been used (Table 1). This data set was provided by the Meteorological Organization of Fars province from 1997 to 2016 for the 20-year statistical period, and then qualitative control was applied on the data.

In order to study the conditions favourable to the bee and to investigate the climatic potential of the Fars province for the beekeeping industry, the heat demand of the bee was studied first. The honey bee reaches its maximum activity at $20-26{ }^{\circ} \mathrm{C}$ and continues to function well up to $6{ }^{\circ} \mathrm{C}$ upper and lower this temperature range. From $32{ }^{\circ} \mathrm{C}$ to $39{ }^{\circ} \mathrm{C}$ and from $14{ }^{\circ} \mathrm{C}$ to $8{ }^{\circ} \mathrm{C}$, they gradually decrease their activities and do not leave their hive at temperatures below $8{ }^{\circ} \mathrm{C}$ or more than $39^{\circ} \mathrm{C}[9]$.

To determine the best location for beekeeping, the temperatures of all months were calculated at different altitudes based on the thermal optimization using the relationship between temperature and altitudes and linear regression equation (Table 3). Probability of occurrences of tolerable thermal temperatures of the honey bee (less than $8{ }^{\circ} \mathrm{C}$ and more than $39^{\circ} \mathrm{C}$ ) is calculated at a confidence level of $75 \%$ using normal distribution.

TABle 1. CHARACTERISTICS OF WeAther Stations StUdied IN THE FARs PROVINCE

\begin{tabular}{lllll}
\hline Station type & Latitude & Longitude & Above sea level & Station name \\
\hline Synoptic & 31.183 & 52.667 & 2030 & Abadeh \\
Synoptic & 30.900 & 52.633 & 2300 & Eghlid \\
Synoptic & 28.783 & 54.283 & 1098 & Darab \\
Synoptic & 30.183 & 82.283 & 1650 & Doroodzan \\
Synoptic & 29.783 & 52.717 & 1596 & Zarghan \\
Synoptic & 29.533 & 52.600 & 1484 & Shiraz \\
Synoptic & 28.967 & 53.683 & 1288 & Fasa \\
Synoptic & 27.683 & 54.283 & 792 & Lar \\
Synoptic & 27.367 & 53.200 & 405 & Lamerd \\
\hline
\end{tabular}


TABLE 2. REGRESSION LINE EQUATIONS OF CORRELATION RELATION BY LINEAR REGRESSION IN 9 STATIONS IN FARS PROVINCE

\begin{tabular}{|c|c|c|c|c|c|}
\hline $\begin{array}{l}\text { Maximum } \\
\text { absolute } \\
\text { temperature }\end{array}$ & $\begin{array}{l}\text { Minimum } \\
\text { absolute } \\
\text { temperature }\end{array}$ & $\begin{array}{l}\text { Maximum } \\
\text { temperature }\end{array}$ & $\begin{array}{l}\text { Minimum } \\
\text { temperature }\end{array}$ & $\begin{array}{l}\text { Average } \\
\text { temperature }\end{array}$ & $\begin{array}{l}\text { Display } \\
\text { Equation and } \\
R \text {-squared } \\
\text { Value }\end{array}$ \\
\hline $\begin{array}{l}y=-0.0082 x+ \\
43.976 \\
R^{2}=0.977\end{array}$ & $\begin{array}{l}y=-0.0085 \mathrm{x}+ \\
10.383 \\
\mathrm{R}^{2}=0.8983\end{array}$ & $\begin{array}{l}\mathrm{y}=-0.0084 \mathrm{x}+ \\
35.287 \\
\mathrm{R}^{2}=0.9835\end{array}$ & $\begin{array}{l}y=-0.0062 x+ \\
17.489 \\
R^{2}=0.9068\end{array}$ & $\begin{array}{l}y=-0.0073 x+ \\
26.359 \\
R^{2}=0.9671\end{array}$ & January \\
\hline $\begin{array}{l}y=-0.0091 x+ \\
51.156 \\
R^{2}=0.9947\end{array}$ & $\begin{array}{l}y=-0.0068 x+ \\
14.129 \\
R^{2}=0.8438\end{array}$ & $\begin{array}{l}y=-0.0091 x+ \\
42.942 \\
R^{2}=0.9874\end{array}$ & $\begin{array}{l}y=-0.0065 x+ \\
22.912 \\
R^{2}=0.8995\end{array}$ & $\begin{array}{l}y=-0.0078 x+ \\
32.925 \\
R^{2}=0.9715\end{array}$ & February \\
\hline $\begin{array}{l}y=-0.0079 x+ \\
52.903 \\
R^{2}=0.9869\end{array}$ & $\begin{array}{l}y=-0.0082 x+ \\
21.047 \\
R^{2}=0.7117\end{array}$ & $\begin{array}{l}y=-0.0084 x+ \\
47.789 \\
R^{2}=0.989\end{array}$ & $\begin{array}{l}y=-0.0065 x+ \\
27.03 \\
R^{2}=0.8691\end{array}$ & $\begin{array}{l}y=-0.0075 x+ \\
37.385 \\
R^{2}=0.9674\end{array}$ & March \\
\hline $\begin{array}{l}y=-0.0068 x+ \\
53.06 \\
R^{2}=0.9761\end{array}$ & $\begin{array}{l}y=-0.0058 x+ \\
21.525 \\
R^{2}=0.6383\end{array}$ & $\begin{array}{l}y=-0.0073 x+ \\
48.857 \\
R^{2}=0.9811\end{array}$ & $\begin{array}{l}y=-0.006 x+ \\
29.709 \\
R^{2}=0.8365\end{array}$ & $\begin{array}{l}y=-0.0066 x+ \\
39.26 \\
R^{2}=0.9493\end{array}$ & April \\
\hline $\begin{array}{l}y=-0.0073 x+ \\
53.27 \\
R^{2}=0.98\end{array}$ & $\begin{array}{l}y=-0.0072 x+ \\
24.698 \\
R^{2}=0.7911\end{array}$ & $\begin{array}{l}y=-0.0072 x+ \\
48.076 \\
R^{2}=0.9716\end{array}$ & $\begin{array}{l}y=-0.007 x+ \\
31.113 \\
R^{2}=0.8665\end{array}$ & $\begin{array}{l}y=-0.0071 x+ \\
39.595 \\
R^{2}=0.947\end{array}$ & May \\
\hline $\begin{array}{l}y=-0.0072 x+ \\
50.953 \\
R^{2}=0.975\end{array}$ & $\begin{array}{l}y=-0.0077 x+ \\
20.533 \\
R^{2}=0.7774\end{array}$ & $\begin{array}{l}y=-0.0073 x+ \\
45.754 \\
R^{2}=0.9816\end{array}$ & $\begin{array}{l}y=-0.0066 x+ \\
27.169 \\
R^{2}=0.8601\end{array}$ & $\begin{array}{l}y=-0.007 x+ \\
36.461 \\
R^{2}=0.963\end{array}$ & June \\
\hline $\begin{array}{l}y=-0.008 x+ \\
47.907 \\
R^{2}=0.953\end{array}$ & $\begin{array}{l}y=-0.0078 x+ \\
14.683 \\
R^{2}=0.7137\end{array}$ & $\begin{array}{l}y=-0.0079 x+ \\
41.549 \\
R^{2}=0.9928\end{array}$ & $\begin{array}{l}y=-0.0064 x+ \\
21.72 \\
R^{2}=0.8598\end{array}$ & $\begin{array}{l}y=-0.0071 x+ \\
31.672 \\
R^{2}=0.9676\end{array}$ & July \\
\hline $\begin{array}{l}y=-0.0084 x+ \\
42.982 \\
R^{2}=0.9955\end{array}$ & $\begin{array}{l}y=-0.0069 x+ \\
7.4643 \\
R^{2}=0.8196\end{array}$ & $\begin{array}{l}y=-0.0081 x+ \\
34.948 \\
R^{2}=0.9932\end{array}$ & $\begin{array}{l}y=-0.006 x+ \\
15.928 \\
R^{2}=0.8598\end{array}$ & $\begin{array}{l}y=-0.0071 x+ \\
25.438 \\
R^{2}=0.9712\end{array}$ & August \\
\hline $\begin{array}{l}y=-0.0065 x+ \\
35.309 \\
R^{2}=0.867\end{array}$ & $\begin{array}{l}y=-0.007 x+ \\
3.2129 \\
R^{2}=0.798\end{array}$ & $\begin{array}{l}y=-0.0076 x+ \\
27.726 \\
R^{2}=0.9841\end{array}$ & $\begin{array}{l}y=-0.0058 x+ \\
11.372 \\
R^{2}=0.9133\end{array}$ & $\begin{array}{l}y=-0.0068 x+ \\
19.632 \\
R^{2}=0.9768\end{array}$ & September \\
\hline $\begin{array}{l}y=-0.0067 x+ \\
32.875 \\
R^{2}=0.9609\end{array}$ & $\begin{array}{l}y=-0.0113 x+ \\
4.9029 \\
R^{2}=0.8282\end{array}$ & $\begin{array}{l}y=-0.0074 x+ \\
24.261 \\
R^{2}=0.9694\end{array}$ & $\begin{array}{l}y=-0.0059 x+ \\
9.3913 \\
R^{2}=0.9405\end{array}$ & $\begin{array}{l}y=-0.0066 x+ \\
16.826 \\
R^{2}=0.9749\end{array}$ & October \\
\hline $\begin{array}{l}y=-0.0071 x+ \\
34.364 \\
R^{2}=0.9615\end{array}$ & $\begin{array}{l}y=-0.0093 x+ \\
4.3322 \\
R^{2}=0.7575\end{array}$ & $\begin{array}{l}y=-0.0076 x+ \\
25.408 \\
R^{2}=0.9855\end{array}$ & $\begin{array}{l}y=-0.0062 x+ \\
10.484 \\
R^{2}=0.9369\end{array}$ & $\begin{array}{l}y=-0.0069 x+ \\
17.946 \\
R^{2}=0.9786\end{array}$ & November \\
\hline $\begin{array}{l}y=-0.0065 x+ \\
39.035 \\
R^{2}=0.9331\end{array}$ & $\begin{array}{l}y=-0.0083 x+ \\
6.8413 \\
R^{2}=0.8957\end{array}$ & $\begin{array}{l}y=-0.0078 x+ \\
29.874 \\
R^{2}=0.9902\end{array}$ & $\begin{array}{l}y=-0.006 x+ \\
13.386 \\
R^{2}=0.9216\end{array}$ & $\begin{array}{l}y=-0.0066 x+ \\
21.145 \\
R^{2}=0.9706\end{array}$ & December \\
\hline
\end{tabular}

To provide digital maps in the Arc GIS software environment using topographic maps and interpolation and using regression line equation from all temperature values and probabilities of occurrence of the heat threshold of the bee, the maps were digitized and prepared. After that, maps for each of the months of the year were combined. Then, based on the studies on the relationship between ambient temperature and honey performance, the classification of the obtained maps was carried out. 


\section{RESUlts}

The Fars province has severe climatic variation in different parts of the Zagros Mountains due to its special position. Such climate variations and temperature differences require careful planning for the development of beekeeping in the province.

By observing the results obtained from the temperature and climate conditions of the Fars province and comparing it with the thermal needs of the honey bee regarding their activities, we see that many parts the Fars province in different months of the year have climatic conditions for beekeeping.

According to the phenological characteristics of the honey bee and climatic characteristics of meteorological stations of the province in terms of honey bee breeding, the province's territory was divided into 4 groups with excellent, good, moderate and weak capabilities (Annex Fig. 1 to Fig. 12). Accordingly, the following results are obtained from the months of the year.

The beginning of spring and the occurrence of temperatures of $8{ }^{\circ} \mathrm{C}$ and more, is the beginning of the activity of the beekeepers and bees. Of course, due to the diverse climate of the province, this occurrence starts in the warmer areas of the province earlier and later in the province's cold areas. Therefore, based on the average climate of the province, April, with an average temperature of $15^{\circ} \mathrm{C}$, is the best time to change the queen while the bees accept the new queen almost without difficulty. One must refrain from unplugging the hives, unless necessary. Carefully, through the flight hole, it is possible to observe the state of the hive. For example, if the bees carry nectar, and specially pollen, it shows that the population has a queen, eggs and larvae; so, everything inside the hive seems normal. In the case of a lack of honey in the hive, the population should be fed. If there is a long time interval between two blooming in the region and there is no other flowering in the area at that time of year, then the bee population should be provided with mixed syrup/sugar, honey and water in equal proportions in order to prevent any decrease in queen's daily activities and to stop the bees from dreaming about laying eggs due to their free time. They also have to hang the walls into strong hives, so that the bees will knit them. It is the best to add half a floor or a full floor to the hives that are extremely strong in their populations.

In late May and early June, with an average temperature of $22{ }^{\circ} \mathrm{C}$, the population usually reaches its maximum annual strength. May is the month when the production of eggs / larvae is at the highest level in most parts of the province. Therefore, all factors that prevent the larvae from becoming obsolete should be used. If necessary, the queen will be replaced. On the beehives whose population is strong, the honey room should be added on the second floor (half floor or a full floor).

In June, if the population tends to lay eggs, then artificial eggs should be taken immediately. In June, the queen usually lays her maximum annual eggs and the population is stronger in this month than other months of the year. It is necessary to limit the increase in population to a limited number which aims to replace the population that died in the past winter. Replacement of the queen is possible in June, but not as successfully or comfortably as it is in April, because replacement of the queen in June usually results in more casualties. It is possible to strengthen weak populations by inserting frames from other hives that have larvae, but without hive bees. By mid to late June, the population usually reaches its highest amounts in terms of honey yield comparing annual yield.

Due to the beginning of summer and the rise in temperature at some hours of the day to more than $39^{\circ} \mathrm{C}$, if in June the proportion of population migration to the cooler areas of the province did not take place, it should be done in July. If possible, it would be better to migrate hives 3 or 4 times or more over a year. By the end of July, a bee year is usually close to the end. If necessary, the population with artificial nutrition must stay strong and with more bee colonies. 
In August, the population should be stimulated by feeding it syrup. This syrup can be made with water, sugar and honey, or water and sugar or water and honey in equal proportions. If male-killing has not started in many parts of the province, it will begin and be completed in this month. The end of the male-killing is the beginning of a new year for the bees. Robbing can damage the bee. Due to lack of flowers and nectar, bees are ready to loot poor populations. They are just waiting for an exciting excuse. Avoid all factors that induce looting in the bees. In September, male-killing ends. The looting can be rampant in this month and the next. Due to the approaching fall and the lowering of temperatures, it is necessary to start winter feeding with vigour and to finish it. The weakening of the population from this month is a natural phenomenon. It is better to unite the very poor populations first and then start feeding. The side of the flight holes should be opposite to the wind region. Queens of the very poor populations can be replaced by the special autumn method. Winter nutrition should end in October at the latest. It is advisable to narrow down the holes to about $1 \mathrm{~cm}$. It is possible to check the condition of the hives from October to April, weighing them every 15 days. To be safe from cold, you can cover the frames with linen cloths and newspaper, and narrow the poor population. It is better to clean the hives for the winter. The number of bees in this month is not important, only the amount of larvae and eggs is important. The more larvae and eggs there are, the stronger the population will be the following spring. Usually in November, bees form winter clusters and continue to live until the early spring. In December, in the cold parts of the province, all bees live in winter clusters. Only on days when the air temperature rises to $8{ }^{\circ} \mathrm{C}$, bees leave the hive, quickly discharge their faeces and return to the hive immediately. In the event of a snowfall, clean the flight hatch of the hive. Bees bear extreme cold, but the smallest airflow can wipe them out. One should check the holes once a week, and if you find abnormal conditions, note the hive number, and during the warm hours of a sunny day, quickly control and eliminate defects. In the hot days of January, if any activities were not seen in the flight hole, one should ultimately and quickly, but in a relaxed manner, open and control the hive and make sure the bees are alive.

In February, when the population does not have enough food, it should be fed with sweet pastry. It is better to control the linen fabrics on the frames and, if necessary, replace them and put some papers on them, so that it will be effective to help the bees to warm their hive. Nuzma disease intensifies in this month, especially in wet areas. As soon as the temperature of the air goes up to $8{ }^{\circ} \mathrm{C}$, the bees flow out and return to their hives after the excretion of the stool.

In March, the queen's livestock activity is higher than in February. Hives should be kept warm and nutrition should be provided with honey or sweet pastry, as the populations have been eating more food this month than the previous month. Observing bees carrying pollen through the flight hole, the bees' relaxation while visiting the hive and also presence of eggs and larvae indicate the viability of the queen.

Based on the results of this research and the use of the resulting maps, beekeepers can choose the best places to deploy their hives in different months of the year in the province.

\section{Discussion}

Temperature is one of the most important factors affecting the honey bee and beekeeping. Identifying optimal thermal conditions is one of the most important measures for the economic use of beekeeping and its products. Considering the importance of the temperature factor in various bee activities, the methods used in this study have been performed around the axis of the climate element of temperature. It is very important to evaluate the optimal thermal conditions based on the occurrences of the daily and monthly minimum and maximum temperatures, as well as the determination of the probability of occurrence of the bee's tolerable heat threshold. The 
optimal heat conditions of the beekeeping activity follow the geographical conditions of the area, especially the elevation factor.

Therefore, in general, the study area can be divided into 3 parts: the southern and western lowlands with a height of less than 1100 meters, the central areas of the province with an average height of 1100 to 1900 meters, and high and northern areas with a height of more than 1900 meters above sea level (Annex Fig. 13). Indeed, in Annex Fig. 13, the altitude map of regions in Fars province is presented to help illustrate the analysis in the discussion.

The southern and low-western areas of Fars province include most parts of the Lamerd, Mohr, Khonj, Gerash, Larestan, Ghir and Karzin, Farashband, Kazerun and low-lying areas of Mamasani, Rostam, Jahrom, Darab, Fasa, and Zarindasht. These areas are very suitable for wintering in the cold seasons. However, from mid-spring, these areas have a heat constraint and beekeepers are better off shifting their colonies to the higher and northern areas of the province.

The central areas of the province, which include the highlands of Rostam, Mamasani, Jahrom, Fasa, Darab and also Shiraz, Firouzabad, Kavar, Sarvestan, Kherame, Marvdasht, Arsanjan, Estahban, Neyriz and low-lying areas of Sepidan and Pasargad are suitable places to spend spring until early summer. In terms of the summer season, the high and northern regions of the province include the highlands of Sepidan and Pasargad and also Bavanat, Khorambid, Eghlid and Abadehare are good places for beekeeping. In May and October, the best conditions for optimal beekeeping exist in the entire province. In the study area for fixed beekeeping, the central strip of the province with an average height of 1500 meters above sea level is the most suitable place.

\section{Conclusions}

The beekeeping industry plays its role in pollination and, as a result, also in maintaining the flora of the forests, pastures, the environment and also increasing agricultural production. Beekeeping in each region relies on conditions and characteristics such as climate and vegetation condition. In this research, due to the high importance of the temperature in bees' activities and their production rate, the daily minimum and maximum temperatures of the meteorological stations were used in a 20-year statistical period. The data were used for adjustment of effective temperature thresholds on bee activities and identification of the active and passive months of honey bee grazing. Then the beekeeping capability map was drawn for the Fars province based on the months of the year.

Regarding different climate of the province, it was impossible to provide a single beekeeping calendar for the entire province. Therefore, in this research, we tried to use the geographic information system (GIS) and provide a zoning map according to the months of the year in order to enable beekeepers to choose an optimal place for beekeeping.

Active heat conditions begin in most parts of the province from the month of April, and gradually reach the highlands of the province. The southern and lower parts of the province have a heat constraint in the months of June to September and it is better to transfer colonies to higher central and northern parts of the province.

The results and achievements of this study in Fars province as a new experience in the field of climate studies are of great importance with an emphasis on climatic and geographical aspects of thermal optimization and presentation of regional beekeeping maps in addition to the development of beekeeping in the fertility of crops and gardens. Finally, according to the results of this study, it is suggested that the impact of climate parameters on the activity of bees inside and outside the hive should be evaluated and investigated as well as the effects of climate change on the activity of bees. 


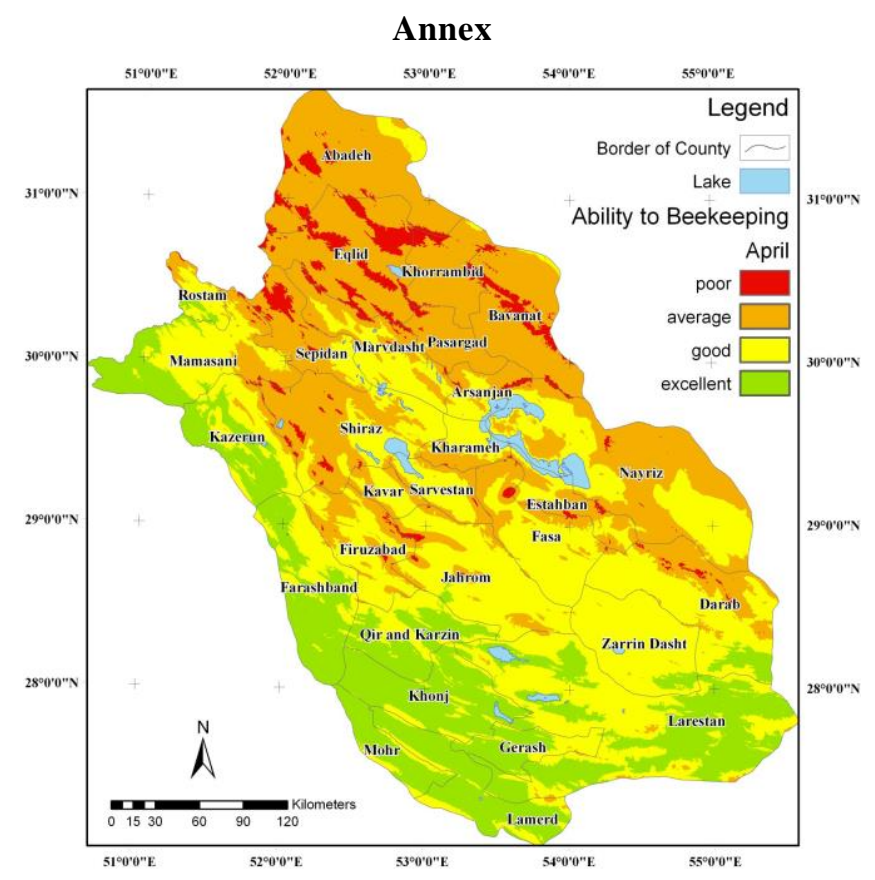

Fig. 1. Suitability of climate conditions for beekeeping in April.

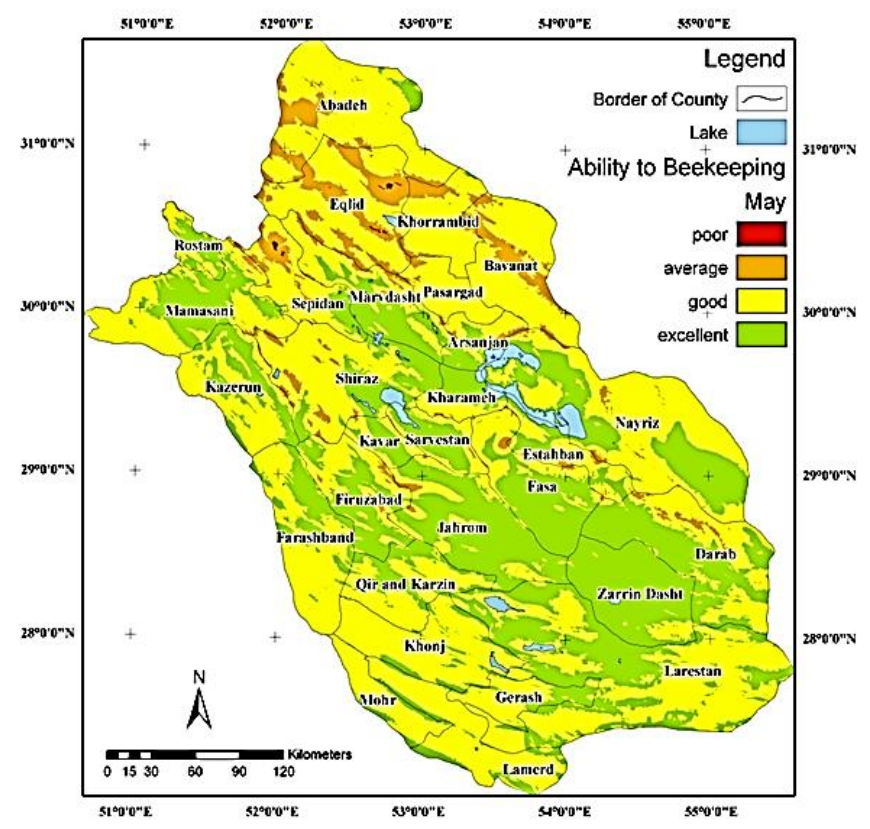

Fig. 2. Suitability of climate conditions for beekeeping in May. 


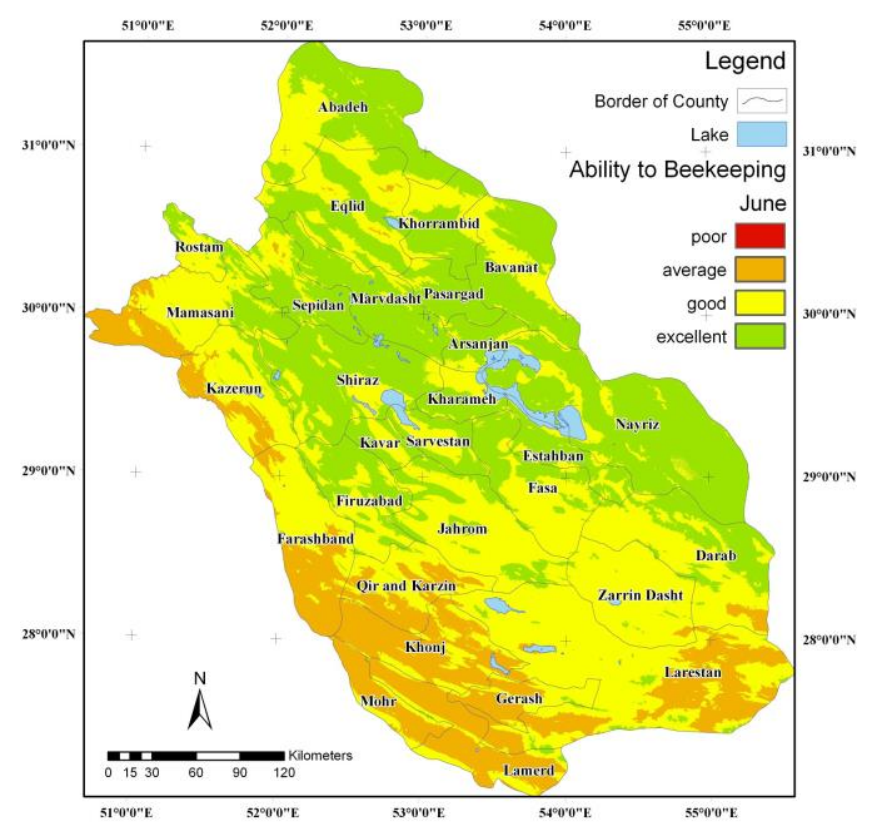

Fig. 3. Suitability of climate conditions for beekeeping in June.

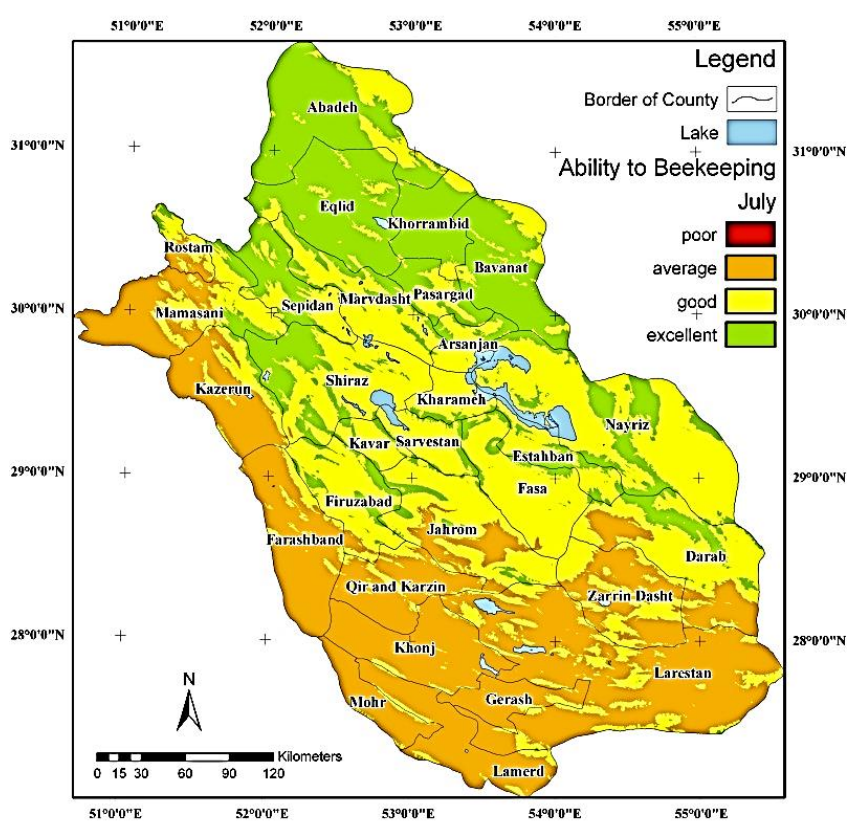

Fig. 4. Suitability of climate conditions for beekeeping in July. 


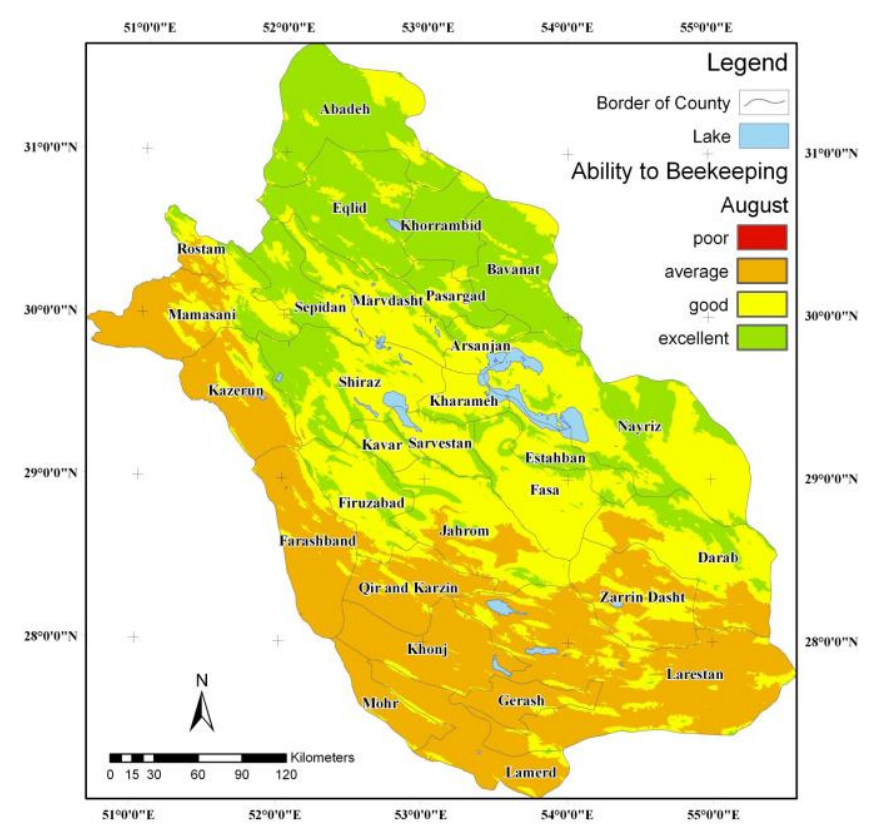

Fig. 5. Suitability of climate conditions for beekeeping in August.

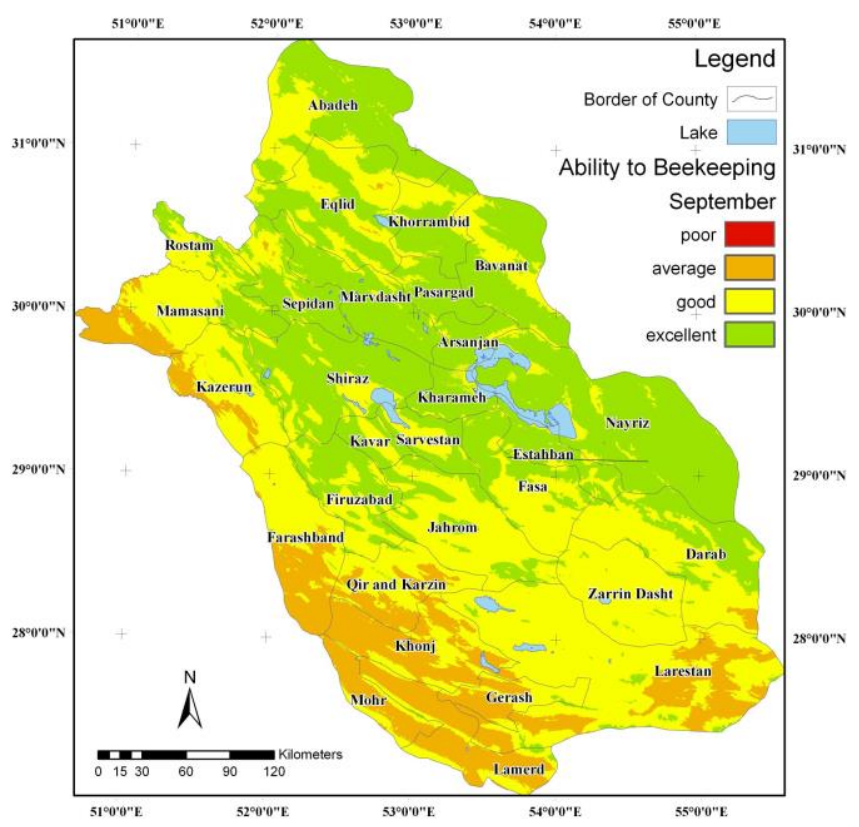

Fig. 6. Suitability of climate conditions for beekeeping in September. 


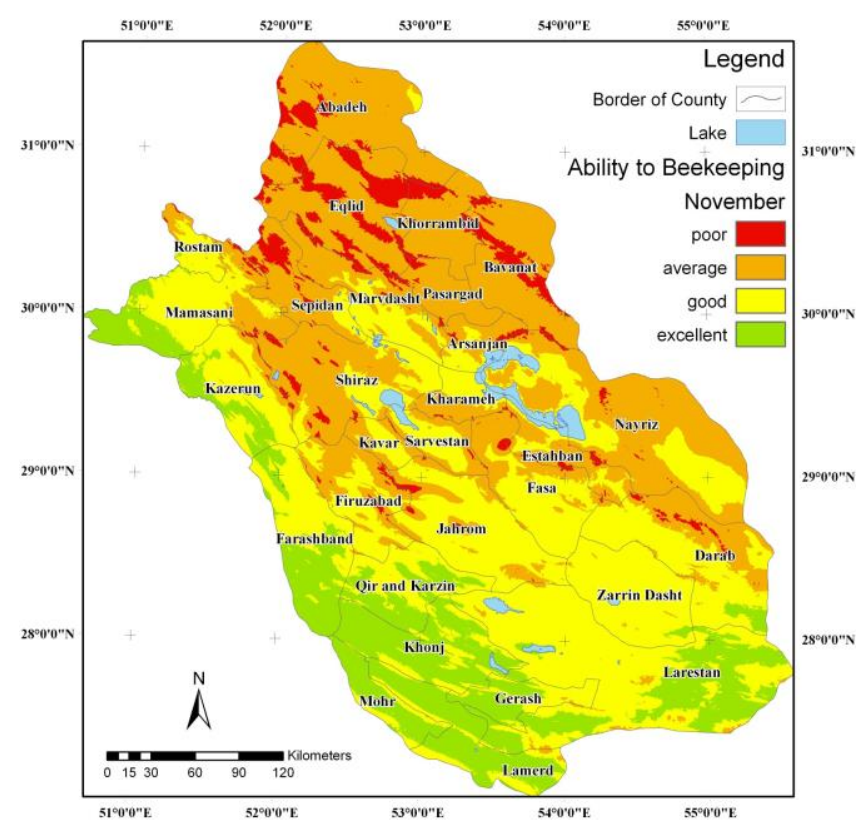

Fig. 7. Suitability of climate conditions for beekeeping in October.

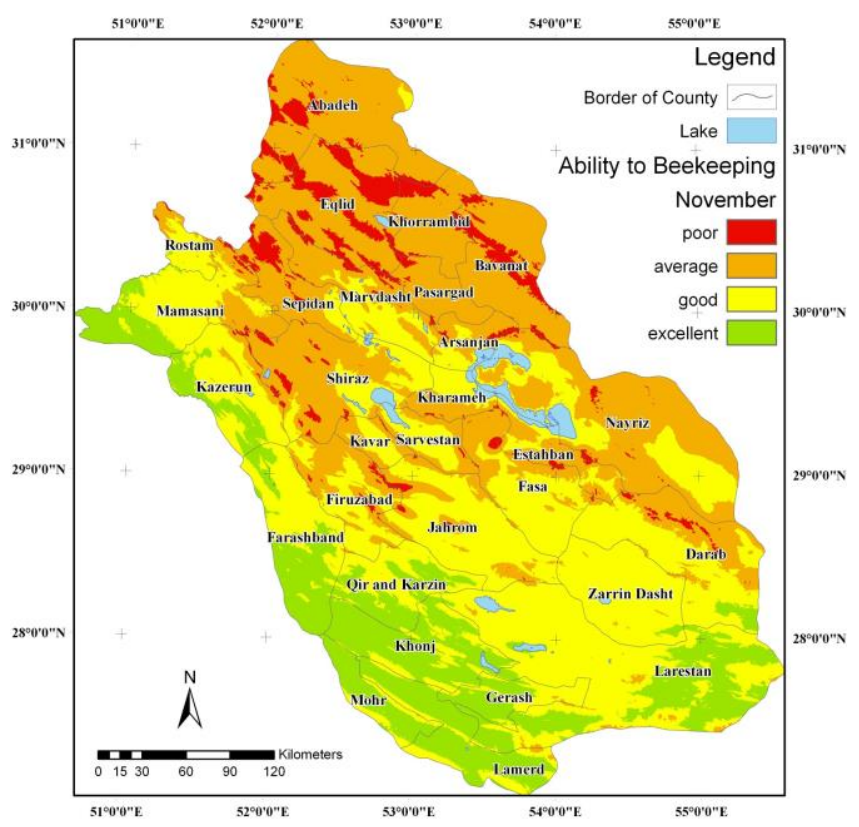

Fig. 8. Suitability of climate conditions for beekeeping in November. 


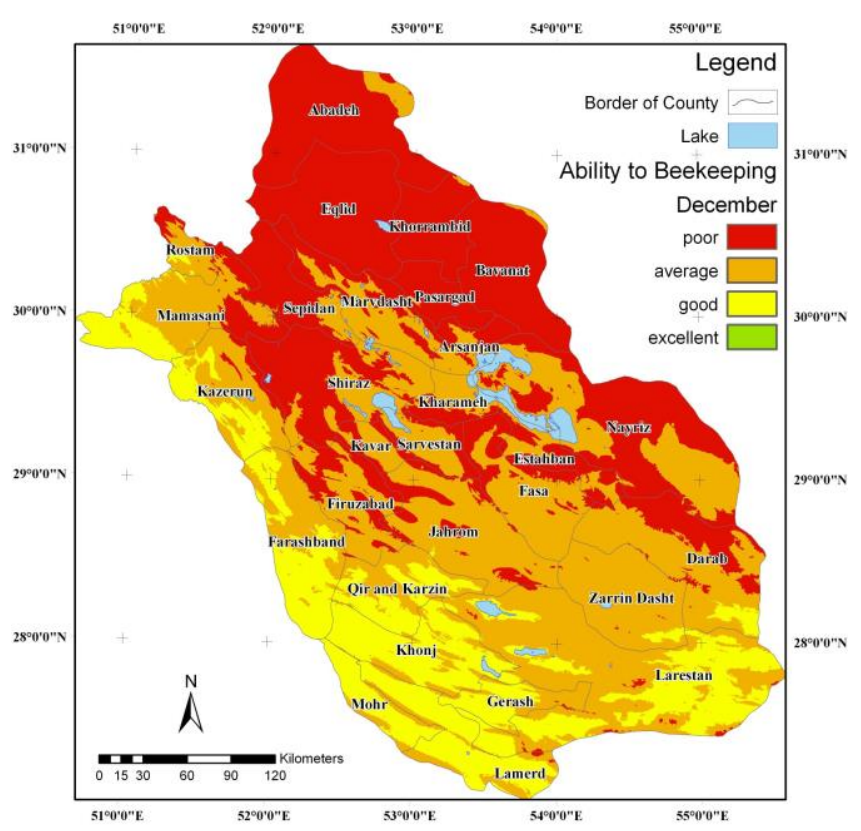

Fig. 9. Suitability of climate conditions for beekeeping in December.

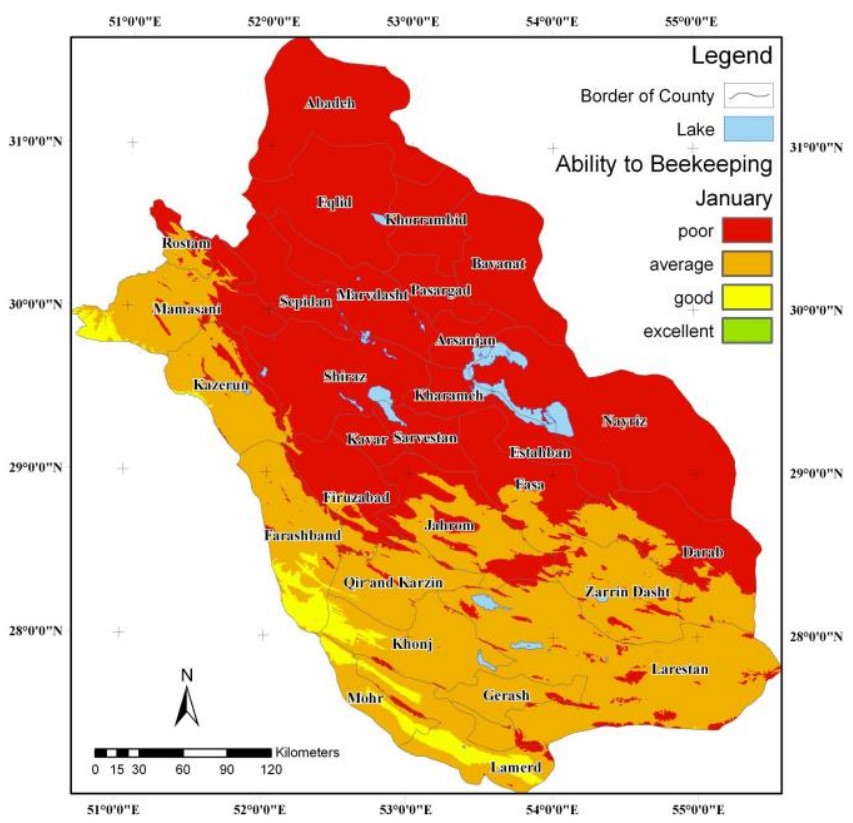

Fig. 10. Suitability of climate conditions for beekeeping in January. 


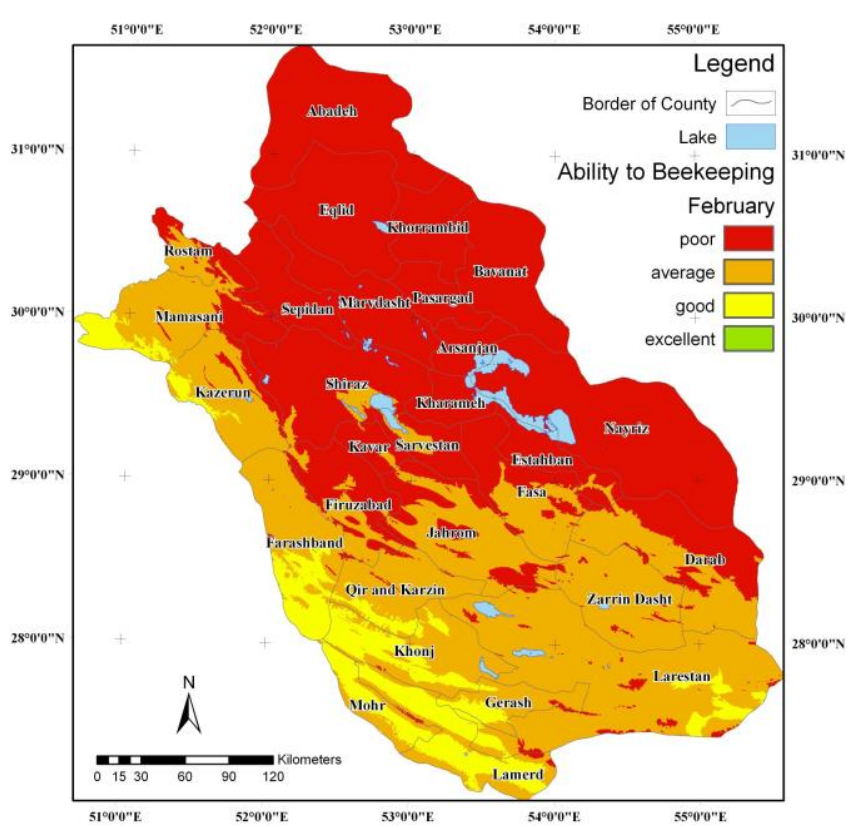

Fig. 11. Suitability of climate conditions for beekeeping in February.

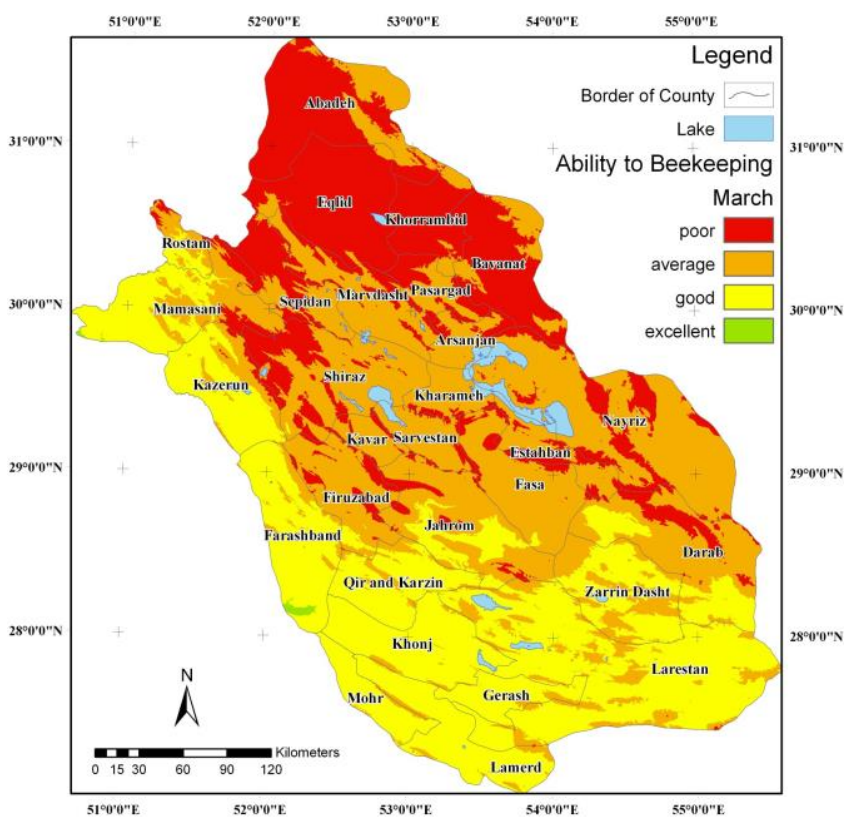

Fig. 12. Suitability of climate conditions for beekeeping in March. 


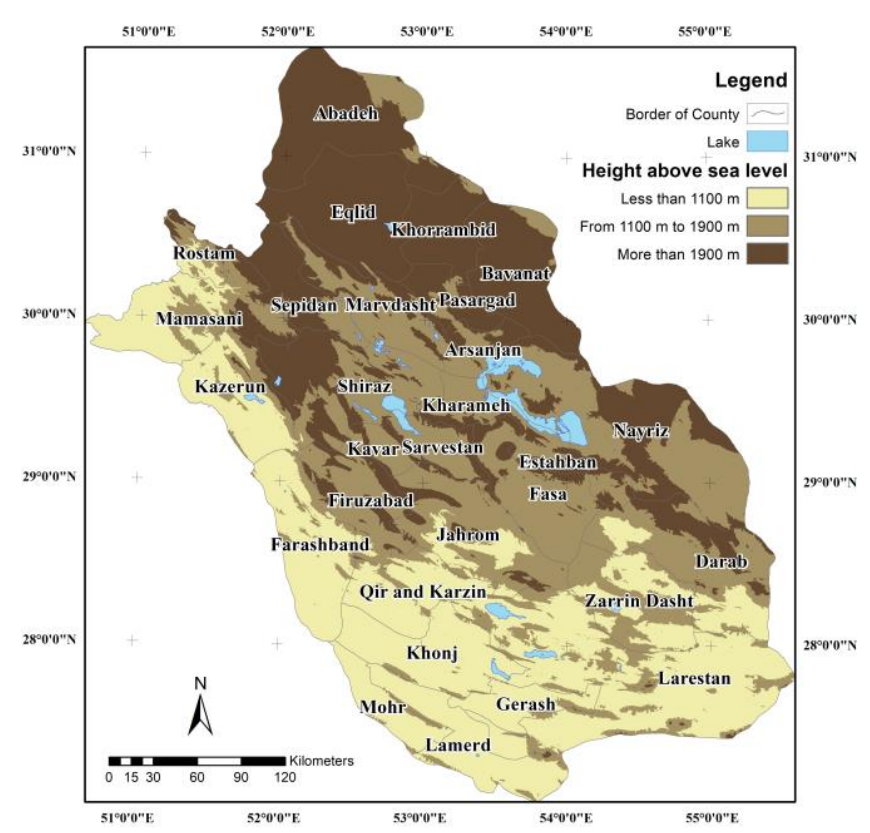

Fig. 13. Altitude Map of Fars Province Regions.

\section{REFERENCES}

[1] Mutsaers M., Blitterswijk van H., Leven van ’t L., Kerkvliet J., Waerdt van de J. Bee products. Wageningen: Digigrafi, 2005.

[2] Pir-Irani E. Beekeepers and beekeeping, first edition. Tehran: Ayizh Publishing, 2015.

[3] Reda, G., Girmay, S., Gebremichael, B. Beekeeping practice and honey production potential in Afar Regional State, Ethiopia. Acta Universitatis Sapientiae, Agriculture and Environment 2018:10(1):66-82. https://doi.org/10.2478/ausae-2018-0006

[4] James R. R., Pits-Singer T. L. Bee pollination in agricultural ecosystems. Oxford: Oxford University Press, Inc, 2008.

[5] Bradbear N. Bees and role in forest livelihoods: A guide to the services provided by bees and the sustainable harvesting processing and marketing of their products. Rome: F. A. O. United nations, 2009.

[6] Shaemi A. Investigating the bioclimatic aspects of bee growing in Iran. Master thesis in Geography. Tarbiat Modarres University, 1992.

[7] Najmi Ghare Gheshlaghi Y. Investigation of climatic elements and its influence on beekeeping in Salmas city. Master thesis. Tarbiat Modarres University, 1999.

[8] Maricen K. Nielsen A., Sttenseth N. C. Potential effects of climate change on crop pollination. Rome: F. A. O. United nations, 2011.

[9] Shahrestani N. Honeybee and its cultivation, fourteenth edition. Tehran: Sepehr publishing, 2006.

[10] Moradi M. Climate and bee change. Presented at 2nd Nat. Conf. on climate change and its effect on agriculture and environment, Urumiye, Iran, 2013.

[11] Avotniece Z., Klavins M., Rodinovs V. Changes of Extreme Climate Events in Latvia. Environmental and Climate Technologies 2012:9(1):4-11. https://doi.org/10.2478/v10145-012-0010-1

[12] Blumberga D., Chen B., Ozarska A., Indzere Z., Lauka D. Energy, Bioeconomy, Climate Changes and Environment Nexus, Environmental and Climate Technologies 2019:23(3):370-392. https://doi.org/10.2478/rtuect-2019-0102

[13] Maddahi K. Climate and pollination change. Iranian Journal of Bee Research and Technology 2014:2(9):20-46.

[14] Shaemi A., et al. Evaluation of climatic potential of bee colony breeding at selected stations in Ilam province in order to develop agriculture. Presented at 1st Nat. Conf. on sustainable development of agriculture using the agricultural model, Ilam, Iran, 2013. 
[15] Rahmani S., et al. Climatic study of phonological studies for beekeeping in Ilam Province. Presented at 4th Sci. Student Conf. in Geography, Ilam, Iran, 2012.

[16] Cressey D. Climate change crushes bee populations. Nature 2015:10:1038-17950. https://doi.org/10.1038/nature.2015.17950

[17] Algamdy A. Evaluation of various honey bee foraging activities for identification of potential bee plants in Riyadh Saudi Arabia. Bee Research 2013.

[18] Ismail A. H. M., Owayss A. A., Mohanny K. M., Salem R. A. Evaluation of pollen collected by honey bee Apismellifera colonies at fayoum governorate Egypt, part 1: Botanical origin. Journal of the Saudi Society of Agriculture Sciences 2013:12(2):129-135. http://dx.doi.org/10.1016/j.jssas.2012.09.003

[19] Abou-Shaara H. F., Al-Ghamdi A., Mohamed A. A suitability map for keeping honey bees under harsh environmental condition using geographical information system. World Applied Sciences Journal 2013.

[20] Bartomeus I., Ascher J. S., Wagner D., Danforth B. N., Colla S., Kornbluth S., Winfree R. Climate-associated phenological advances in bee pollinators and bee-pollinated plants. Proceedings of the National Academy of Sciences 2011:20645-20649. http://dx.doi.org/10.1073/pnas.1115559108

[21] Tahmasebi G. et al. Effect of geographical and climatic conditions on the separation of small honeybee masses in Iran. Journal of Science and Technology of Agriculture and Natural Resources 2002:6(2):169-175.

[22] Golchin Mostafa et al. Investigating the effect of climate elements on modern honeybees performance in Ahar province. Quarterly journal of geographical space 2010:29:181-197.

[23] Larti M., Nazarian H, Ghasempoor S., Shanaki P., Khodakarimi A. Production of bee keeping calendar of Nazluchay and Rozechay watershed in West Azerbaijan Province. Journal of animal science (research and production) 2013:333.

[24] Jazayeri S. Deputy Director of Improvement of livestock production in agricultural organization of Fars Province [Online]. [Accessed 14.06.2011]. Available: http://www. farsnews.com

[25] Sotoudeh J. Poultry, Honeybee and silkworm Moderator of Fars Agricultural organization. Shiraz Journalists' club.

[26] Rozentale L., Blumberga D. Methods to Evaluate Electricity Policy from Climate Perspective. Environmental and Climate Technologies 2019:23(2):131-147. https://doi.org/10.2478/rtuect-2019-0060

[27] Beigloo H. B., Dastjerdi K. Climatic regions of Fars Province by factor analysis. Geographical space magazine 2010:10(32):135-150.

[28] Pande R., Ramkrushna G. I. Diversification of Honey bees' flora and bee flora calendar for Nagpur and Wardha districts of Maharashtra, India. Journal of Entomology and Zoology Studies 2018:6(2):3102-3110.
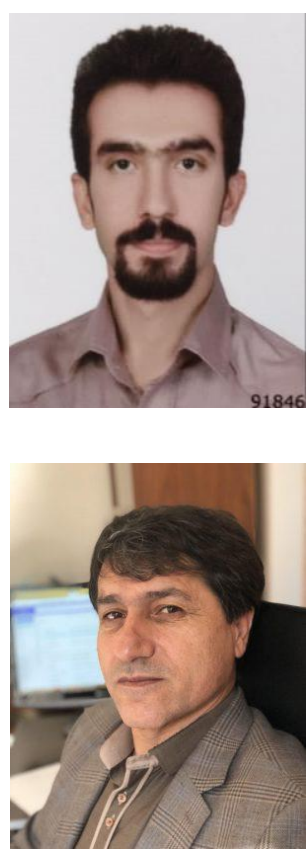

Ali Akbar Salehizadeh defended Ph. D. thesis in 2019. Completed the B.S. in Islamic Azad University, Banab-Branch, the M.A. in Physical Geography and started the Ph. D. in physical Geography-Climatology in 2013. He has written four articles, published two of them in Iranian journals and two others in Mediterranean Journal of Social Sciences, Italy, May 2015. He is professional in working with Word, Excel, Arc GIS, Auto CAD, Surfer, Grads, Matlab, etc. He achieved EPT in English.

E-mail: En_salehizadeh@yahoo.com

Morteza Khodagholi, associate professor at Rangelands and Forests of Institute Research, Agricultural Research Extension Education Organization (AREEO), Tehran, Iran. Received a B.S. in Range Management in 1986 and M.Sc. in 1993. Completed the PhD in Climatology in 1999. Attended 40 research activities and 97 conferences presenting posters and delivering lectures. Morteza Khodagholi is an author of 4 books and a co-author of 2 books. The published papers mainly focus on plant ecology, environment, ecological features, draught and precipitation.

E-mail: m khodagholi@yahoo.com

ORCID iD: https://orcid.org/0000-0001-7969-6386 


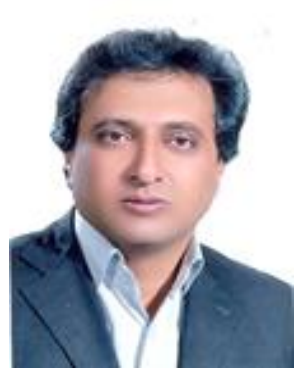

Amir Gandomkar, associate professor in the Faculty of Humanities, Najafabad branch, Islamic Azad University, University Blvd. Najafabad, Isfahan Iran. Received the B.A in Human Gegraphy and the M.A. in Natural Geography. Defended the Ph. D in Climatology. Taught Climatology, GIS, Computer, Human and Environment, etc in universities. An author of publications in the Journal of Environmental Research and Development, 2007 and 2011 , Wulfenia, 2011, the Journal of Basic and Applied Scientific Research, 2013. An author of 31 paper publications in Iran.

E-mail: aagandomkar@yahoo.com

ORCID iD: https://orcid.org/0000-0002-9344-7607 